\title{
A new record of the Japanese Longhorn decorator crab Chorilia japonica (Miers, 1879) (Crustacea: Brachyura: Epialtidae) in the western part of Bering Sea - the first record of the species and genus for Russian waters
}

\author{
Новая находка японского острорылого краба-декоратора \\ Chorilia japonica (Miers, 1879) (Crustacea: Brachyura: Epialtidae) \\ в западной части Берингова моря \\ - первая находка вида и рода для вод России
}

\author{
Ivan N. Marin ${ }^{1}$, Peter K.L. $\mathrm{Ng}^{2}$, Sergey E. Anosov ${ }^{3}$

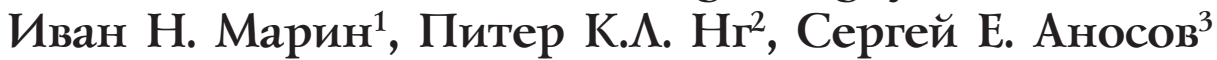

\begin{abstract}
1A.N. Severtzov Institute of Ecology and Evolution of RAS, Leninsky prosp., 33, Moscow, 119071, Russia. Email: coralliodecapoda@mail.ru, vanomarin@yahoo.com

${ }^{2}$ Department of Biological Science, National University of Singapore, 14 Science Drive 4, 117543, Singapore. Email: dbsngkl@nus.edu.sg ${ }^{3}$ Russian Federal Research Institute of Fishery and Oceanography, V. Krasnoselskaya str., 17, Moscow, 107140, Russia. E-mail: anosov@vniro.ru, anosov@aquarius-s.ru

${ }^{1}$ Институт проблем экологии и эволюции им. А.Н. Северцова РАН, Ленинский проспект, 33, Москва, 119071, Россия. ${ }^{3}$ Всероссийский научно-исследовательский институт рыбного хозяйства и океанографии (ВНИРО), ул. Верхняя Красносельская, 17, Москва, 107140, Россия.
\end{abstract} KEY

КЛЮЧЕВЫЕ СЛОВА. Crustacea, Decapoda, Epialtidae, Chorilia, новая находка, Берингово море, Cеверное полушарие, Россия.

ABSTRACT. A male specimen of Chorilia japonica (Miers, 1879) (Crustacea, Brachyura, Epialtidae) was collected in the Bering Sea, southwest of Navarin Cape, at the depth of 283-298 m. This represents the first record of the genus Chorilia Dana, 1851 for Russia and is the most northern record of the genus in north-western Pacific; and is a range extension of more than $3000 \mathrm{~km}$ for the species. The specimen is diagnosed and the taxonomy of the genus discussed.

РЕЗЮМЕ. Самец краба Chorilia japonica (Miers, 1879) (Crustacea, Brachyura, Epialtidae) обнаружен в Беринговом море, в районе Мыса Наварин, на глубине 283-298 м. Этот вид и род крабов впервые обнаружен в водах России, а также данная находка является самой северной для рода в северо-западной части Тихого Океана, увеличивая область распространения рода почти на 3000 км. Представлено описание собранного экземпляра и обсуждение таксономии данного рода.

\section{Introduction}

According to WoRMS the longhorn decorator crab genus Chorilia Dana, 1851 (Brachyura, Majoidea, Epialtidae) represently includes three valid species, all from the northern Pacific: C. japonica (Miers, 1879) (central to northeastern Japan), C. longipes Dana, 1851 (type species, Alaska to Monterey Bay, California), $C$. turgida Rathbun, 1924 (Monterey Bay to San Diego, California and Cortex Bank, Mexico) [Miers, 1879; Rathbun, 1925; Sakai, 1976; Ng et al., 2008; Hendrickx, in press; WoRMS]. The genus resembles both Rochinia A. Milne-Edwards, 1875 and Hyastenus White, 1847 by a V-shape rostrum diverging from its base, the absence of an intercalated spine between the supraorbital eave and postorbital tooth. Nevertheless Chorilia can be separated from Rochinia by the spinulation of dorsal surface of carapace and tropical distribution of the latter genus [Ng, Richer de Forges, 2007; $\mathrm{Ng}$ et al., 2008], from Hyastenus only by the fact that the preobital spine is long and sharp, and the diameter of the cornea is no wider than the ocular peduncle in Chorilia [Sakai, 1976; Griffin, Tranter, 1986]; in Hyastenus, the preobital spine is low, and the diameter of the cornea is wider than the ocular peduncle. Chorilia also grows to larger sizes than Rochinia and Hyaste$n u s$, reaching sizes of 50-70 $\mathrm{mm}$ in carapace length, and is restricted to sublittoral area of higher latitudes of the Northern Hemisphere [Rathbun, 1925; Sakai, 1976]. Although Chorilia is known from northern Japan, it has not been reported from any location further north, with no previous records from the Sea of Japan, Russian Okhotsk and Bering Seas [Marin, 2013a, b]. 
However, during a fishing survey on the vessel "Stella Karina" in June 2014, the third author collected one male specimen of Chorilia in a trawl in the Bering Sea, southwest of Navarin Cape, at the depth of 283$298 \mathrm{~m}$. This is the first record of the genus Chorilia for Russia and the most northern record in the western North Pacific. The specimen best agrees with Chorilia japonica and represents a substantial range extension for the species of more than $3000 \mathrm{~km}$.

\section{Material and methods}

The single mature male (cl $47.0 \mathrm{~mm}$, cw $25.0 \mathrm{~mm}$ ) was collected by third author by dredging on trawler "Stella Karina" in west part of Bering Sea, south-east of Navarin Cape, $61^{\circ} 5.2^{\prime} \mathrm{N} 179^{\circ} 4.8^{\prime} \mathrm{W}-61^{\circ} 57.1^{\prime} \mathrm{N} 179^{\circ}$ $3.7^{\prime} \mathrm{W}$, at the depth of $283-298 \mathrm{~m}$, with water temperature about $3.2-3.7^{\circ} \mathrm{C}$, in 2 June 2014 . Other animals in the same trawl were pandalid and crangonid shrimps Pandalus borealis, Argis ovifer, Neocrangon communis as well as remains of unidentified suberitid sponges, brittle stars, sea urchins, squids and fishes. The collected specimen was photographed alive and then fixed with $70 \%$ solution of ethanol. The specimen is deposited the collection of Zoological Museum of Moscow State University (ZMMU). Carapace length (cl, in $\mathrm{mm}$ ), the distance from tip of rostrum to postero-dorsal margin of carapace, and carapace width (cw, in $\mathrm{mm}$ ), the distance between lateral margins of carapace in its widest part, are used as standard measurements. Only primary synonyms are given.

\section{Taxonomy}

Epialtidae MacLeay, 1838

Chorilia Dana, 1851

\section{Chorilia japonica (Miers, 1879) \\ Fig. 1.}

Hyastenus (Chorilia) japonica: Miers, 1879: 27 [type locality: Japan, $41^{\circ} 40^{\prime} \mathrm{N} 141^{\circ} 10^{\prime} \mathrm{E}, 100$ fathoms]

MATERIAL EXAMINED. Mature male (cl $47.0 \mathrm{~mm}$, cw 25.0 $\mathrm{mm}$ ), ZMMU - Pacific Ocean, west part of Bering Sea, south-east of Navarin Cape, trawler "Stella Karina", trawl No.50, 61 $5.2^{\prime} \mathrm{N}$ $179^{\circ} 4.8^{\prime} \mathrm{W}-61^{\circ} 57.1^{\prime} \mathrm{N} 179^{\circ} 3.7^{\prime} \mathrm{W}, 283-298 \mathrm{~m}, 3.2-3.7^{\circ} \mathrm{C}$, coll S. Anosov, 2 June 2014. Other animals in the same trawl were pandalid and crangonid shrimps Pandalus borealis, Argis ovifer, Neocrangon communis as well as remains of unidentified suberitid sponges, brittle stars, sea urchins, squids and fishes.

BRIEF DIAGNOSIS OF MALE (Fig. 1). Carapace pyriform; regions demarcated, gastric region with 2 sharp median tubercles, anterior one larger, epibranchial spines short, sharp, curved anteriorly; rostrum long (ca. 0.5 carapace length), spines long, slender, straight, diverging from base forming deep V-shape; preocular spine prominent, acutely triangular, directed obliquely; without intercalated spine between supraocular eave and postocular tooth; narrow U-shaped hiatus between supraocular eave and postocular tooth; basal antennal article long, narrow, with proximal spine and slender anterolateral spine; chelipeds elongated, dorsal margin of merus with 2 sharp teeth on proximal half, ventral margin with scattered small tubercles, dorsal and ventral margins of chela cristate; ambulatory legs elongated, subcylindrical, merus, carpus and propodus unarmed.

REMARKS. The genus Chorilia has generally been regarded as containing only one boreal species, $C$. longipes Dana, 1851, with three subspecies: C. longipes longipes Dana, 1851, C. longipes turgida Rathbun, 1924, and C. longipes japonica (Miers, 1879) [see Rathbun, 1925: 202; Garth, 1958: 263; Griffin, Tranter, 1986: 112]. Ng et al. [2008: 102] treated all three as full species. The differences between the two American species have been discussed at length by Rathbun [1925] and Garth [1958], and are most easily separated by the degree of spinulation on the dorsal surface of the carapace (more spinulated in C. turgi$d a$ ), the proportions of the movable articles of the antenna (relatively more slender and longer in C. turgi$d a$ ) and their mostly discrete distributions (see earlier). Chorilia japonica was described by Miers [1879: 27] from Japan, and he noted that it differed mainly from the American taxa by possessing relatively shorter more divergent, shorter spines on the basal antennal article and less spinulated upper surface of the merus of the cheliped. Of these, the only feature that seems to usually work is the more divergent rostral spines; the other characters being too variable. Although American Chorilia species usually have the distal half of the rostral spines being subparallel rather than continuously divergent, it is not always the case [e.g., see Garth, 1958: Pl. 30 fig. 2 for $C$. turgida]. Another character that works in adult specimens is the relative proportion of their ambulatory legs; $C$. japonica has proportionately shorter meri [cf. Fig. 1d; Miers 1879: pl. 1 fig. 2; Sakai, 1976: pl. 78 fig. 3] compared to C. longipes and C. turgida [cf. Rathbun, 1925: pl. 225; Garth, 1958: pl. 30 figs. 1, 2]. A revision examining a large series of specimens of all three species, preferably with molecular-phylogenetic analysis would be useful to throw more light on their taxonomy.

The present specimen from Russia agrees best with C. japonica in all the salient characters discussed above, and it seems best to refer it to this taxon for the time being. Chorilia japonica has been reported from the islands of Shikoku to Hokkaido in Japan [Sakai, 1976; Miyake, 1998]. In view of the substantial distance (some $3000 \mathrm{~km}$ ) between the present location and where it was last reported in Japan, a larger series of specimens from Russia is clearly necessary for further comparisons.

The discovery of $C$. japonica in Russian waters is not surprising and follows reports of several other decapod species recently recorded from Russia and adjacent regions [Marin et al., 2011; Marin, 2013c-e; Hong, Lee, 2014].

ACKNOWLEDGEMENTS. The present study was supported by Grant of the President of the Russian Federation MK-4481.2014.4 and Russian Foundation of Fundamental Research (grants \#\# 14-04-10183_k, 15-04-05125_a). The 


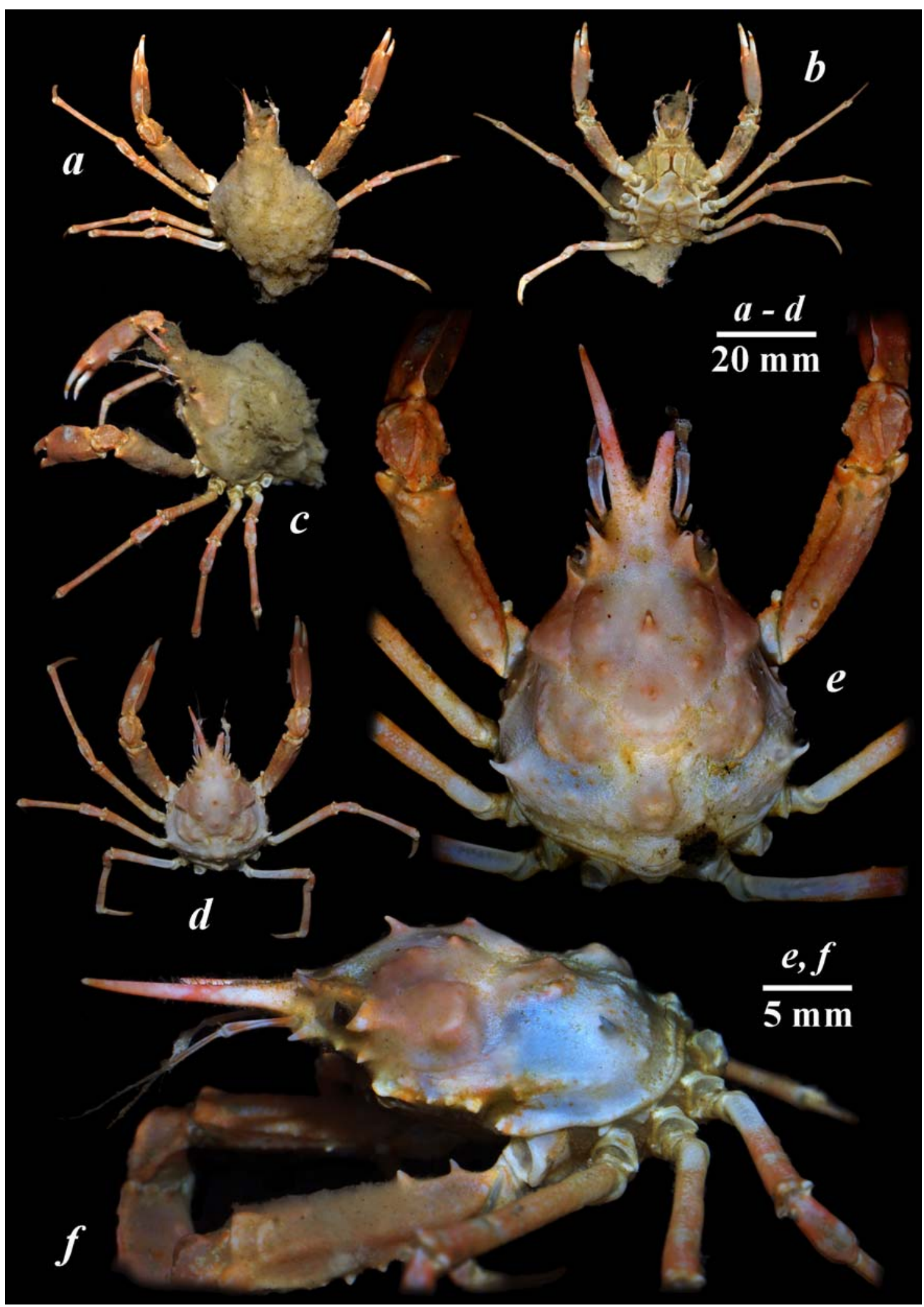

Fig. 1. Male specimen of Chorilia japonica (Miers, 1879), ZMMU, from western part of Bering Sea: $a-c-$ specimen covered by small sponge (possibly, Suberitidae); $d$ - cleaned specimen, dorsal view; $e$ - carapace, dorsal view; $f$ - carapace, lateral view.

Рис. 1. Самец Chorilia japonica (Miers, 1879), ZMMU, из западной части Берингова моря: $a-c-$ внешний вид только что выловленного животного, обросшего губками (возможно из семейства Suberitidae); $d$ - очищенный от губок экземпляр, вид сверху; $e$ - карапакс, вид сверху; $f$ - карапакс, вид сбоку. 


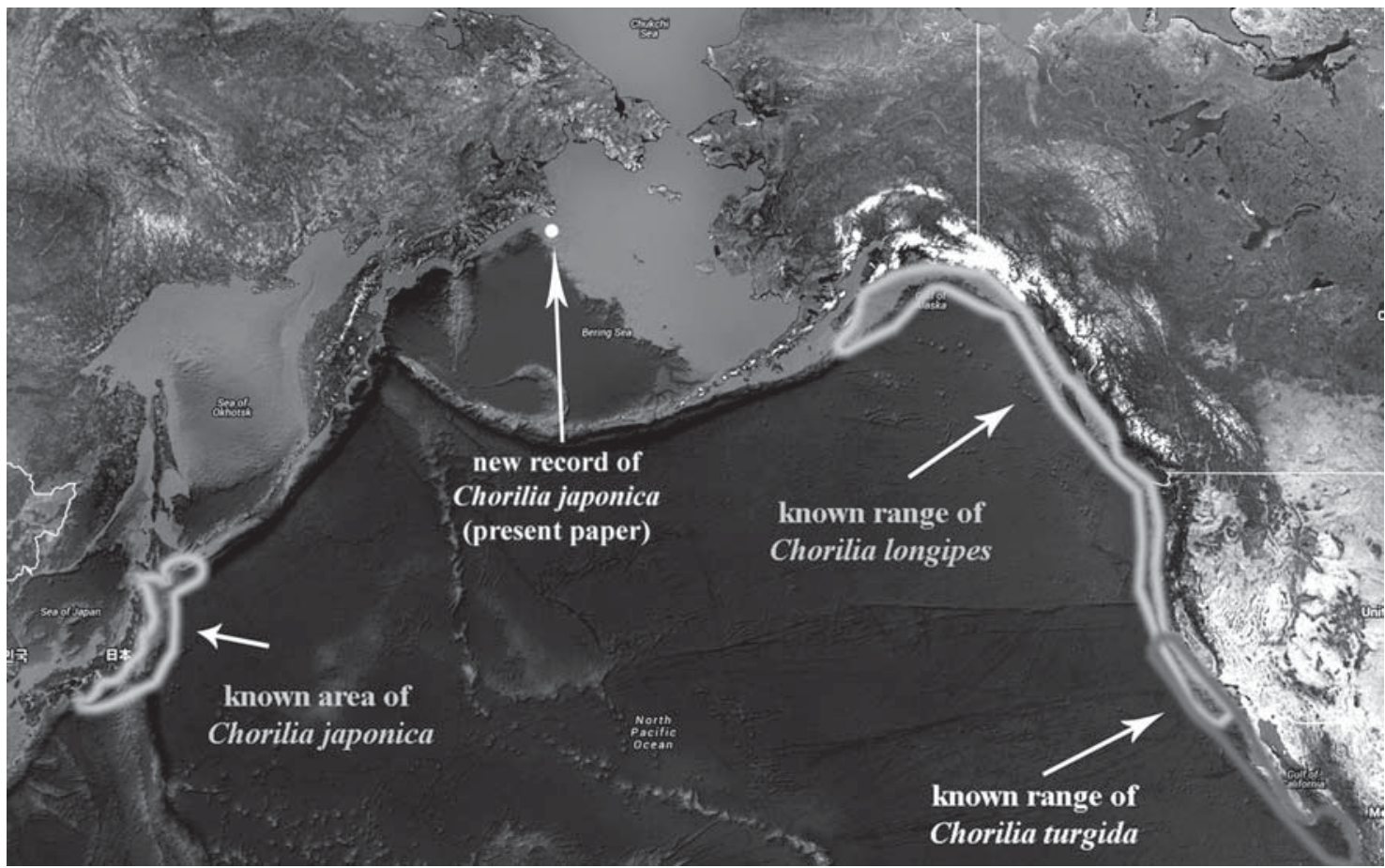

Fig. 2. Known geographical ranges of representatives of Chorilia Dana, 1851 in the northern Pacific.

Рис. 2. Географическое распространение представителей рода Chorilia Dana, 1851 в северной части Тихого Океана.

authors are very thankful to the crew of the R/V "Stella Karina" for the assistance during sampling.

\section{References}

Garth J.S. 1958. Brachyura of the Pacific coast of America: Oxyrhyncha // Allan Hancock Pacific Expeditions. Vol.21. No.12. P.1-874.

Griffin D.J.G., Tranter H.A. 1986. The Decapoda Brachyura of the Siboga Expedition. Part VIII. Majidae // Siboga-Expeditie. Vol.39C4. P.1-335.

Hong J., Lee C.-L. 2014. First Finding of the Mud Shrimp Upogebia yokoyai Makarov, 1938 (Crustacea: Decapoda: Upogebiidae) in Korean Waters // Ocean and Polar Research. Vol.36. No.3. P.235-246.

Hendrickx M.E. (in press). First records of Chorilia turgida Rathbun, 1924 (Decapoda, Brachyura, Majoidea, Epialtidae) from the Pacific coast of Mexico // Revista Mexicana de Biodiversidad.

Marin I.N., Korn O.M., Kornienko E.S. 2011. Symbiotic crab Sestrostoma balssi (Shen, 1932) (Varunidae: Gaeticinae) from Vostok Bay, Sea of Japan: a new species for the fauna of Russia // Russian Journal of Marine Biology. Vol.37. No.6. P.509-510.

Marin I.N. 2013a. [Atlas of Decapod Crustaceans of Russia]. Moscow: KMK Scientific Press. 145 p. [in Russian].

Marin I. 2013b. Infraorder Brachyura // Sirenko B. (ed.). [Checklist of species of free-living invertebrates of the Russian Far Eastern Seas"]. Publication of ZIN RAS. P.120-121. http:// www.zin.ru/ZooDiv/pdf/dv list.pdf

Marin I.N. 2013c. New Data on the Distribution of Hairy Clawed Shore Crabs of the Genus Hemigrapsus (Decapoda: Varunidae) along the Russian Mainland Coast of the Sea of Japan // Russian Journal of Marine Biology. Vol.39. No.4. P.301-305.

Marin I. 2013d. Upogebia yokoyai Makarov, 1938 (Decapoda: Gebiidea: Upogebiidae) - a new species of gebiid shrimps for fauna of the Sea of Japan // Biologya Morya. Vol.13. No.3. P. 221-226.
Marin I. 2013e. A new species of callianassid ghost shrimp of the genus Nihonotrypaea Manning \& Tamaki, 1998 (Crustacea, Decapoda, Axiidea, Callianassidae) from southern part of the Russian coast of the Sea of Japan // Zootaxa. Vol.3694. No.5. P.434-444.

Miers E.J. 1879b. On a Collection of Crustacea made by Capt. H. C. St. John, R.N. in the Corean and Japanese Seas. Part I. Podophthalmia. With an Appendix by Capt. H. C. St. John // Proceedings of the Zoological Society of London. Vol.1879(I). P.18-61.

Milne-Edwards A. 1873-1881. Etudes sur les Xiphosures et les Crustacés de la région mexicaine // Mission scientifique au Mexique et dans l'Amérique Centrale / Recherches Zoologique sur la Faune d'Amérique Centrale et du Mexique. Part 5. Vol.1. Paris: Imprimerie Nationale. 368 p.

Miyake S. 1998. Brachyura (Crabs) // Japanese Crustacean Decapods and Stomatopods in Color. Third Printing. Osaka, Hoikusha. Vol.2. 277 p.

Ng P.K.L., Richer de Forges B. 2007. A new species of deep-water spider crab of the genus Rochinia A. Milne-Edwards, 1875, from Guam (Crustacea: Brachyura: Majidae) // Zootaxa. Vol.1610. P.61-68.

Ng P.K.L., Guinot D., Davie P.J.F. 2008. Systema Brachyurorum: Part I. An annotated checklist of extant brachyuran crabs of the world // Raffles Bulletin of Zoology. Supplement. Vol.17. P.1286.

Rathbun M.J. 1924. New species and subspecies of spider crabs // Proceedings of the United States National Museum. Vol.64. P.1-5.

Rathbun M.J. 1925. The Spider Crabs of America // U. S. National Museum Bulletin. Vol.129. P.1-613.

Sakai T. 1976. [Crabs of Japan and the Adjacent Seas]. In three volumes. Kodansha Ltd. Tokyo. English Text. 773 p.

White A. 1847. Descriptions of new Crustacea from the Eastern Seas // Proceedings of the Zoological Society of London. Vol.15(CLXXII). P.56-58.

WoRMS - World Register of Marine Species. http://www. marinespecies.org/

Responsible editor V.A. Spiridonov 